\title{
Efflux Pump Gene Expression in Erwinia chrysanthemi Is Induced by Exposure to Phenolic Acids
}

\author{
Ramani S. Ravirala, ${ }^{1}$ Ravi D. Barabote, ${ }^{2}$ David M. Wheeler, ${ }^{3}$ Sylvie Reverchon, ${ }^{4}$ Ouwatha Tatum ${ }^{5}$ \\ Jeremy Malouf, ${ }^{5}$ Hui Liu, ${ }^{6}$ Leighton Pritchard, ${ }^{6}$ Peter E. Hedley, ${ }^{6}$ Paul R. J. Birch, ${ }^{6}$ Ian K. Toth, ${ }^{6}$ \\ Paxton Payton, ${ }^{3}$ and Michael J. D. San Francisco ${ }^{1}$ \\ ${ }^{1}$ Department of Biological Sciences and Center for Biotechnology and Genomics, Texas Tech University, Lubbock 79409, \\ U.S.A.; ${ }^{2}$ Department of Biological Sciences, University of California-San Diego, San Diego, U.S.A.; ${ }^{3}$ United States \\ Department of Agriculture-Agricultural Research Service Cropping Systems Research Laboratory, Lubbock, TX 79415, \\ U.S.A.; ${ }^{4}$ Unité de Microbiologie et Genetique, UMR CNRS-INSA-UCB 5122, 69622 Villeurbanne, France; ${ }^{5}$ School of \\ Allied Health, Texas Tech University Health Sciences Center, Lubbock 79410, U.S.A.; ${ }^{6}$ Scottish Crop Research Institute, \\ Dundee, Scotland
}

Submitted 10 June 2006. Accepted 20 September 2006.

Salicylic acid (SA) is an important signaling molecule in local and systemic plant resistance. Following infection by microbial pathogens and the initial oxidative burst in plants, SA accumulation functions in the amplification of defense gene expression. Production of pathogenesisrelated proteins and toxic antimicrobial chemicals serves to protect the plant from infection. Successful microbial pathogens utilize a variety of mechanisms to rid themselves of toxic antimicrobial compounds. Important among these mechanisms are multidrug-resistance pumps that bring about the active efflux of toxic compounds from microbial cells. Here, we show that a combination SA and its precursors, $t$-cinnamic acid and benzoic acid, can activate expression of specific multidrug efflux pump-encoding genes in the plant pathogen Erwinia chrysanthemi and enhance survival of the bacterium in the presence of model as well as plant-derived antimicrobial chemicals. This ability of plant-pathogenic bacteria to co-opt plant defense-signaling molecules to activate multidrug efflux pumps may have evolved to ensure bacterial survival in susceptible host plants.

Additional keywords: acrA, bacterial resistance, emrA.

In response to microbial attack, plants activate defense responses that lead to induction of a broad spectrum of antimicrobial defenses (Van Loon 2000). These induced defenses are expressed not just locally but also in parts distant from the site of primary infection, thereby protecting the plant from spread of an infection and future attack. Induced resistance is regulated by a network of interconnecting signal transduction pathways in which salicylic acid (SA) is a key signaling molecule (Feys and Parker 2000; Pieterse and Van Loon 1999). SA-dependent resistance has been shown to be specific to microbial pathogens (Delaney et al. 1994; Wildermuth et al. 2001).

One of the earliest responses of plants to pathogen attack is the generation of an oxidative burst that can trigger hypersensitive cell death (Greenberg 1996). This hypersensitive response (HR) is associated with increased synthesis of lignin, callose,

Corresponding author: Michael J. D. San Francisco; Telephone: 806-7422706; Fax: 806-742-2963; E-mail: michael.sanfrancisco@ttu.edu and antimicrobial compounds such as phytoalexins that help to limit pathogen spread. The HR finally leads to the induction of systemic acquired resistance (SAR). The development of SAR results in a broad spectrum of resistance to subsequent infections (Dangl 1998; Klessig et al. 2000; Mauch-Mani and Slusarenko 1996). The HR also may be induced during plant responses to non-host-specific bacterial pathogens such as $E r$ winia chrysanthemi that utilize a type III secretion system to deliver proteins into the plant cytosol or the plant intercellular space (Alfano and Collmer 1997, Bauer et al. 1994). Plant cell wall fragments (oligogalacturonides), generated by the action of cell-wall-degrading enzymes, notably pectinases, produced by $E$. chrysanthemi, induce pathways of phenylpropanoid metabolism in plants generating phenolic acids such as SA and a wide array of antimicrobial proteins and chemicals, including quinones, flavonoids, phenolics, coumarins, terpenes, and alkaloids (Cowan 1999; Hahn et al. 1981; Hammerschmidt 1999; Ryan and Farmer 1991; Tenhaken et al. 1995).

SA is derived primarily from phenylalanine, with trans-cinnamic acid (TC) and benzoic acid (BA) serving as intermediates (Chong et al. 2001; Coquoz et al. 1998; Mauch-Mani and Slusarenko 1996; Ryan and Farmer 1991; Yalpani et al. 1993). Phenylalanine ammonia lyase (PAL) that catalyzes the first step in the pathway converting phenylalanine to TC has been shown to rise in pathogen-inoculated leaves continually for 18 h (Smith-Becker et al. 1998).

Although our understanding of E. chrysanthemi virulence factors and their regulation has become increasingly clear (Collmer and Keen 1986, Hugouvieux-Cotte-Pattat et al. 1996), we have a less complete understanding of how this bacterium survives in the plant following infection and how it tolerates the onslaught of plant antimicrobial chemicals. The importance of gene products involved in resistance to antimicrobial peptides, repair of oxidatively damaged proteins, protection from nitrosoative stress, and attenuation of host HR during infection have been demonstrated (Boccara et al. 2005; El Hassouni et al. 1999; Lopez-Solanilla et al. 1998, 2001; Nachin at al. 2001; Okinaka et al. 2002). We have demonstrated that the outer membrane protein TolC which, together with multidrug efflux proteins, forms a continuous channel across the periplasm and both membranes, is essential for bacterial resistance to antimicrobial chemicals and survival in plant tissue (Barabote et al. 2003). Analysis of the E. chrysan- 
themi genome shows that it contains homologs of Escherichia coli $\mathrm{Acr} A \mathrm{~B}$ and EmrAB efflux pumps to remove toxic antimicrobial chemicals from the cell and, recently, the importance of several efflux pumps has been demonstrated (Valecillos et al. 2006).

Here, we show that $E$ chrysanthemi efflux pump gene expression is upregulated in plant tissue and also in the presence of the phenolic acid signaling molecules. Additionally, tolerance of the bacterium to model and plant-derived antimicrobial agents is enhanced in the presence of these phenolic acids. These studies suggest that bacterial plant pathogens have evolved strategies to co-opt defense-related plant signaling chemicals to enhance their resistance to toxic plant chemicals and, consequently, to ensure survival in a hostile host environment.

\section{RESULTS}

Efflux pump gene expression is induced in plant tissue early in the infection process.

Annotation of the E. chrysanthemi 3937 genome sequence indicates the presence of genes encoding homologs of the Escherichia coli AcrAB and EmrAB efflux pumps (Glasner et al. 2006). These two pumps, as well as others, utilize a common outer membrane protein, TolC, that has been shown to be important for complete removal of toxins from the bacterial cell and is essential for survival of this bacterium in the host (Barabote et al. 2003). Expression of the acrA and emrA genes during the early stages of plant infection was monitored by luciferase or $\beta$-glucuronidase activity, respectively. Gene activity for both these pump-encoding genes was detected just 90 min following whitloof chicory leaf infections (Fig. 1A and B). Growth of bacteria over this 90 -min interval increased approximately 2 -fold and expression of acrA::lux was approxi- mately 50-fold greater than the control. A protein bearing immunological identity to Escherichia coli AcrA with the predicted size of the E. chrysanthemi 3937 AcrA was observed to be induced 90 min following inoculation of E. chrysanthemi cells into whitloof chicory leaves (Fig. 2). These observations suggest that activation of efflux pump-encoding genes takes place before significant bacterial growth occurs in plant tissue and, presumably, before significant build up of antimicrobial chemicals occurs in plant tissue.

\section{Phenolic acids enhance expression of the acrA} and $e m r A$ efflux pump-encoding genes in $E$. chrysanthemi.

Previous studies have shown that SA and weak acids can stimulate efflux pump gene expression in enteric bacteria (Alekshun and Levy 1999; Randall and Woodward 2001; Rosner 1985). Because plants produce SA and other phenolic acids as part of the defense repertoire following infection by microbial pathogens, we decided to test the impact of these chemicals on efflux pump gene expression. Exposure of $E$. chrysanthemi cells for 90 min to phenolic acids at a concentration of $0.078 \mathrm{mM}$ resulted in significant stimulation of $a \mathrm{crA}$ gene expression compared with the dimethyl sulfoxide (DMSO) control (Fig. 3A). Concentrations below and above $0.078 \mathrm{mM}$ did not significantly induce acrA gene expression. At higher

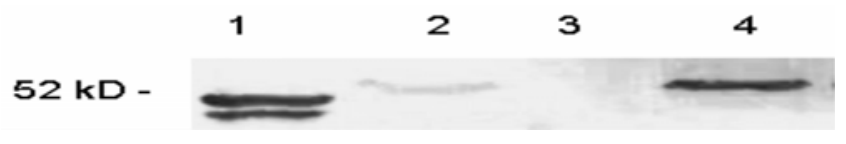

Fig. 2. Immunoblot analysis using anti-AcrA (Escherichia coli) with Erwinia chrysanthemi 3937 whole-cell proteins following infection of plant tissue. Lane 1, Escherichia coli AcrA; (antiserum control); lane 2, Erwinia chrysanthemi (buffer control); lane 3, blank; lane 4, E. chrysanthemi cells recovered after $90 \mathrm{~min}$, following inoculation into plant tissue.
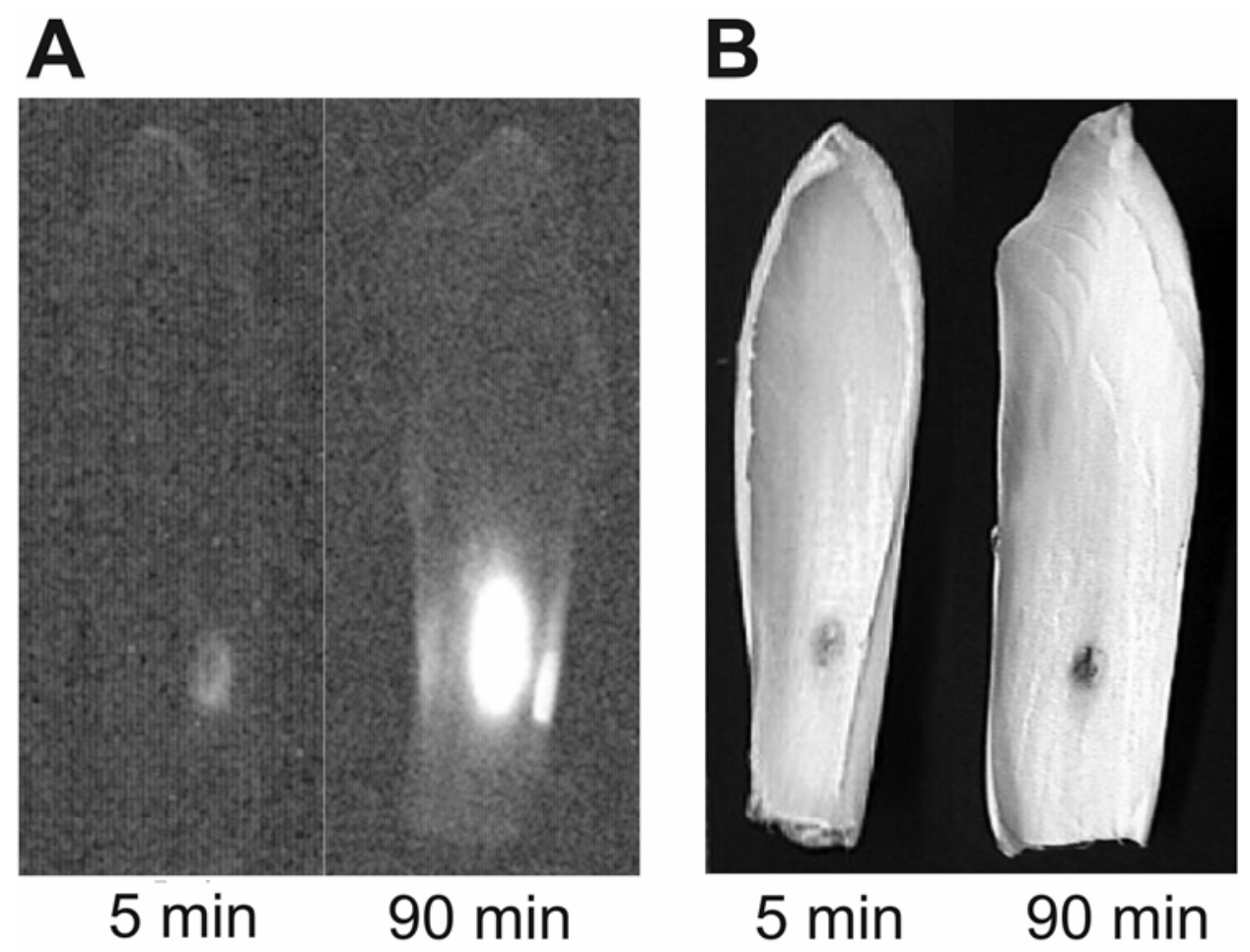

Fig. 1. A, In vivo efflux pump expression of the Erwinia chrysanthemi 3937 acr::lux transcriptional fusion on plasmid pHSK728. Leaves of whitloof chicory were inoculated with $10^{6}$ bacteria from an overnight culture. Measurements were made at 5 and 90 min after inoculation using a Kodak Image Station 440 B, In vivo efflux pump expression of the E. chrysanthemi 3937 carrying the emr::uidA transcriptional fusion on plasmid pBluescript. Leaves of whitloof chicory were inoculated with $10^{6}$ bacteria from an overnight culture. $\beta$-Glucuronidase activity was detected in situ at 5 and 90 min post infection using 5 bromo-4-chloro-3-indolyl- $\beta$-D-glucuronide as a substrate. 
concentrations, the combination of phenolic acids appeared to be toxic and did not stimulate acrA gene expression. These observations suggest that acrA gene expression is highly sensitive to a very narrow range of phenolic acid concentrations. BA was the only phenolic acid that, when used alone, showed significant stimulation of acrA gene activity at concentrations of 0.156 and $0.313 \mathrm{mM}$ compared with the DMSO control (Fig. 3B). Exposure to the other phenolic acids separately resulted in only modest increases in acrA gene activity (data not shown). The most potent inducer of emrA gene activity was found to be SA, which stimulated $\beta$-glucuronidase activity by approximately threefold at $0.313 \mathrm{mM}$.

To obtain a genome-wide perspective on the influence of the combination of phenolic acids and verify our efflux pump reporter gene expression observations, we utilized E. chrysanthemi 3937 microarray experiments. These experiments were conducted in triplicate using Agilent microarrays. Treatment with PA at a concentration of $0.078 \mathrm{mM}$ for $90 \mathrm{~min}$ resulted in a significant $(P<0.05)$ increase (approximately 150 genes) or decrease (approximately 60 genes) over the DMSO control. Expression of three efflux pump-encoding genes (acrA, emrA, and one unknown efflux pump-encoding gene) was significantly upregulated (Table 1). Expression of genes encoding the other efflux pumps (approximately 29 in number) did not show a significant change in expression following this treatment.
The outer membrane protein-encoding gene $\operatorname{ompX}$ which plays a role in antibiotic and detergent (sodium dodecyl sulfate) resistance in Escherichia coli and Yersinia pestis (Otto and Hermansson 2004) also was significantly upregulated. Other genes encoding proteins involved in bacterial oxidative stress resistance, osmC and gst, also were significantly upregulated in these experiments. Escherichia coli lacking OsmC is hypersensitive to $\mathrm{H}_{2} \mathrm{O}_{2}$ and tert-butylhydroperoxide, indicating that the protein is involved either directly or indirectly in defense against oxidative stress (Conter et al. 2001). Glutathione- $S$ -

Table 1. Antibiotic and stress resistance-related genes induced in Erwinia chrysanthemi 3937 following exposure to the combination of phenolic acids (salicylic acid, benzoic acid, and trans-cinnamic acid)

\begin{tabular}{lllc}
\hline ASAP ID $^{\mathbf{a}}$ & \multicolumn{1}{c}{ Gene } & \multicolumn{1}{c}{ Annotation } & $\boldsymbol{t}$ Test $\boldsymbol{P}$ value $^{\mathbf{b}}$ \\
\hline 15971 & emrA & Efflux pump & $3.21 \mathrm{E}-04$ \\
19532 & acrA & Efflux pump & $7.73 \mathrm{E}-03$ \\
18909 & ompX & Outer membrane protein & $8.64 \mathrm{E}-03$ \\
17804 & osmC & Osmotic stress & $7.51 \mathrm{E}-06$ \\
17805 & gst & Stress resistance & $2.47 \mathrm{E}-09$ \\
16284 & Unknown & Efflux pump & $4.58 \mathrm{E}-02$ \\
\hline
\end{tabular}

a ASAP database (Glasner et al. 2006).

b Increases of average signal log ratio from three biological replicates were evaluated by GeneSpring software ( $t$ test, $P$ value $\leq 0.05)$.
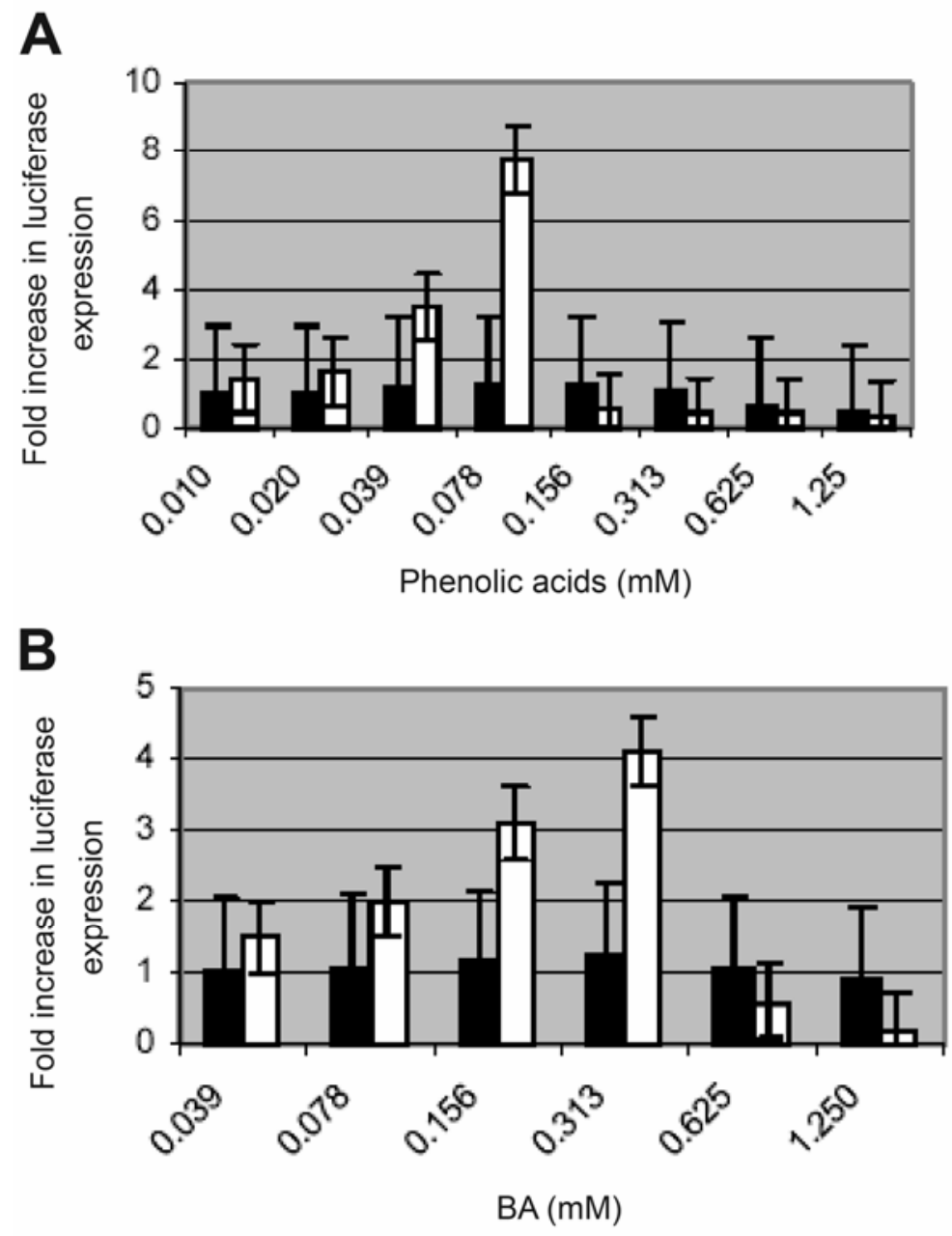

Fig. 3. In vitro acrA::lux response of Erwinia chrysanthemi 3937 exposed for 90 min to A. the combination of phenolic acids (salicylic acid, benzoic acid [BA], and trans-cinnamic acid) or B, BA alone. Statistically significant fold increases in gene expression were observed at the combination of phenolic acids at $0.078 \mathrm{mM}(P<0.005)$ and BA concentrations of 0.156 and $0.313 \mathrm{mM}(P<0.05)$. Measurements were made using a Turner-Roberts luminometer. An average of three separate experiments with error bars representing the standard error of the mean are presented. Phenolic acid treatment ( $\square$ ) and dimethyl sulfoxide solvent as control (ם). 
transferases catalyze the conjugation of hydrophobic substrates, such as drugs, herbicides, and insecticides, to glutathione (GSH) (Eaton and Bammler 1999). This conjugation increases their solubility and facilitates further metabolic processing.

\section{Quantitative real-time}

reverse-transcriptase polymerase chain reaction analysis.

In order to validate our in vivo gene fusion and microarray observations, we utilized real-time quantitative reverse-transcriptase polymerase chain reaction (Q-RT-PCR) using RNA isolated from $E$. chrysanthemi cells exposed to either PA $(0.078 \mathrm{mM})$ or DMSO as a solvent control for $90 \mathrm{~min}$. Experiments were performed using SYBR green with primers specific for acrA, emrA, ompX, and the 16S rRNA-encoding gene (Table 2). Reactions lacking the template served as a negative control. An approximately fivefold induction was observed with $e m r A$, whereas acrA and $o m p X$ each were induced approximately fourfold (Fig 4). There was no notable change in expression for the $16 \mathrm{~S}$ rRNA-encoding gene under these conditions. These data are in good agreement with our microarray and in vivo gene fusion studies.

\section{Tolerance of $E$. chrysanthemi to model and plant antimicrobial agents is enhanced in the presence of phenolic acids.}

To study whether the increase in efflux pump gene expression following exposure to phenolic acids actually translates into enhanced tolerance to antimicrobial agents, we employed a viable cell count assay. In these experiments, each antimicro-

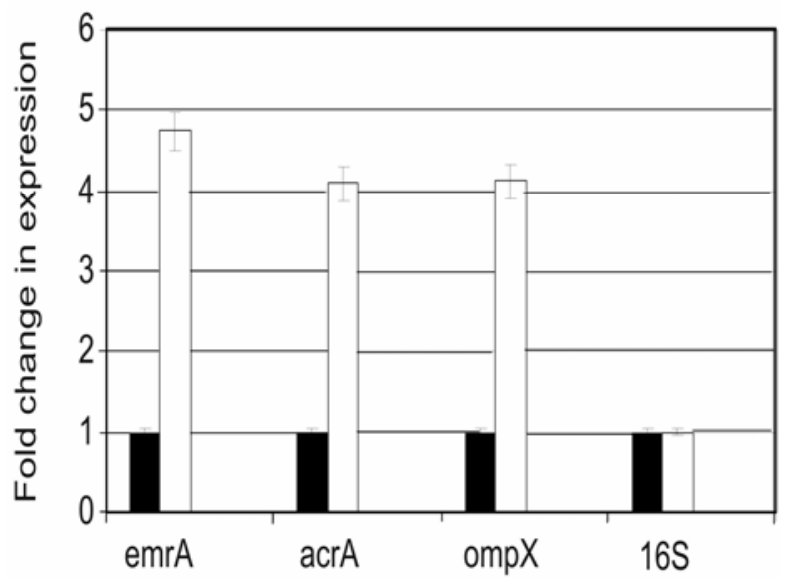

Fig. 4. Quantitative real-time reverse-transcriptase polymerase chain reaction analysis in Erwinia chrysanthemi induced in response to the combination of phenolic acids (salicylic acid, benzoic acid, and trans-cinnamic acid). Fold change in the presence of the phenolic acids $(0.078 \mathrm{mM})(\square)$ or dimethyl sulfoxide control $(\mathbf{\square})$. Statistical analysis to describe the relative relationship between the test and control samples was carried out as previously described (Pfaffl 2001) using the 16S rRNA-encoding gene as an internal control. Results are means from three independent experiments. bial agent was tested at a level just below the MIC. The colony count on agar medium following $12 \mathrm{~h}$ of exposure to the antimicrobial agent in the presence or absence of PA $(0.078 \mathrm{mM})$ was used to determine the relative increase in tolerance. Our results indicate that growth in carbonyl cyanide m-chlorphenylhydrazone (CCCP) or plumbagin (PB) was enhanced approximately two- or eightfold, respectively, in the presence of PA (Table 3). These observations provide relevance to enhanced efflux pump gene expression in the presence of phenolic acids.

\section{DISCUSSION}

Drug efflux pumps in bacteria are recognized as major contributors to bacterial survival. Mutations in efflux pump-encoding genes have been shown to sensitize bacteria to antimicrobial chemicals (Borges-Walmsley and Walmsley 2001; Nikaido 1996). Loss or impairment of efflux pump function also compromises the ability of pathogenic bacteria to cause disease or survive in their hosts. This has been observed in animal pathogens Salmonella enteritidis and Vibrio cholerae (Bina and Mekalanos 2001; Stone and Miller 1995) and in plant-associated bacteria E. chrysanthemi, E. amylovora, Agrobacterium tumefaciens, and Rhizobium etli (Barabote et al. 2003; Burse et al. 2004a,b; Gonzalez-Pasayo and MartinezRomero 2000; Lopez-Solanilla et al. 1998, 2001; Palumbo et al. 1998; Valecillos et al. 2006).

Successful pathogens such as E. chrysanthemi that incite an $\mathrm{HR}$ and ensuing production of antimicrobial chemicals might sense preexisting and newly synthesized phenolic acids that serve in plant signaling. In healthy plants, conjugated BA pools decrease transiently after pathogen attack with concomitant synthesis of SA (Chong et al. 2001; Coquoz et al. 1998). The observation that the combination of phenolics acid or BA alone were the most powerful inducers of bacterial efflux pump gene expression suggests that bacterial defenses may be primed before plant antimicrobial agents are produced. Because

Table 3. Phenolic acids enhance antibiotic resistance in Erwinia chrysanthemi $^{\mathrm{a}}$

\begin{tabular}{lcc}
\hline \multicolumn{1}{c}{ Treatment } & Antibiotic & Antibiotic + phenolic acids \\
\hline CCCP & $9.4 \times 10^{6}$ & $2.1 \times 10^{8}$ \\
Plumbagin & $2.0 \times 10^{5}$ & $1.7 \times 10^{7}$ \\
Novobiocin & $8.1 \times 10^{8}$ & $2.7 \times 10^{9}$ \\
Berberine & $1.9 \times 10^{8}$ & $1.5 \times 10^{9}$ \\
\hline
\end{tabular}

a Tolerance of E. chrysanthemi to antibiotics is enhanced following exposure to a combination of phenolic acids. Values indicate viable cell number per milliliter. Cells were grown in liquid culture and inoculated at $10^{6}$ cell $/ \mathrm{ml}$ into flasks containing subminimal inhibitory concentrations of the antimicrobial agents. Viable counts were determined after growth for $12 \mathrm{~h}$ at $30^{\circ} \mathrm{C}$. Results represent an average of four separate experiments with three replicates each and indicate that there is a statistically significant enhancement of growth following treatment with phenolic acids $(\mathrm{t}$ test, $P$ value $\leq 0.05)$. Inducer phenolic acids salicylic acid, benzoic acid, and trans-cinnamic acid were added at concentration of $0.078 \mathrm{mM}$ each. $\mathrm{CCCP}=$ carbonyl cyanide $\mathrm{m}$-chlorphenylhydrazone.

Table 2. Oligonucleotide primers used in this study

\begin{tabular}{|c|c|c|c|}
\hline Primer & Sequence $5^{\prime}-3^{\prime}$ & Application $^{\mathbf{a}}$ & Product size (bp) \\
\hline acrA F & GGAAGGCAGCGACGTCGG & RT-PCR & \\
\hline acrA R & TTTACGCCCAGTAATTCCGATT & RT-PCR & 50 \\
\hline emrA F & CGCTCAAACGTACCCATATCG & RT-PCR & \\
\hline emrA R & CTGCGGCGGGAGACATAG & RT-PCR & 50 \\
\hline ompX F & CCAGCGATGCTGGTTTTGT & RT-PCR & $\ldots$ \\
\hline ompX R & CGTTCTGAACCGGGTTGAAC & RT-PCR & 50 \\
\hline $16 \mathrm{~S} F$ & CCAGCAGCCGCGGTAAT & RT-PCR & $\ldots$ \\
\hline $16 \mathrm{~S} R$ & TTTACGCCCAGTAATTCCGATT & RT-PCR & 50 \\
\hline
\end{tabular}

${ }^{a}$ RT-PCR = reverse-transcriptase polymerase chain reaction. 
TC and BA are precursors of SA and, conceivably, are present together at an infection site, our observation of efflux pump gene induction by these chemicals together is interesting and relevant.

The $a c r A B$ operon in enteric bacteria encodes a periplasmic, membrane fusion protein, AcrA, and a membrane protein, AcrB (Murakami et al. 2002). This efflux pump functions together with the outer membrane protein TolC to bring about the rapid energy-dependant efflux of a wide variety of antimicrobial agents (Fralick 1996; Koronakis et al. 2000). The importance of components of this tripartite efflux pump has been demonstrated by mutational analysis in the plant pathogens E. chrysanthemi and E. amylovora (Barabote et al. 2003; Burse et al. 2004a,b; Valecillos et al. 2006). The EmrAB efflux pump has a relatively small substrate range when compared with the AcrAB pump in the family Enterobacteriaceae. Whereas the AcrAB pump expels bile salts, dyes, detergents, organic solvents, and antibiotics, the EmrAB pump substrate range is limited to a few ionophores and antibiotics (Borges-Walmsley and Walmsley 2001). Recent work also has demonstrated the contribution of members of the Emr family to drug resistance and phytopathogenicity in E. chrysanthemi (Valecillos et al. 2006).

Our observation of induction of acrA gene expression by phenolic acids was predicted based on previous studies with members of the family Enterobacteriaceae. Transcription of the global transcriptional activator MarA is derepressed in these bacteria following exposure to phenolics such as SA (Grkovic et al. 2001; Miller and Sulavik 1996). The repressor MarR has been shown to bind SA, the inducer of the marAB operon (Alekshun and Levy 1999, Alekshun et al. 2001; Rhee et al. 1998). Screening of the E. chrysanthemi genome sequence reveals the presence of many transcriptional regulators related to the MarR family and transcriptional activators belonging to the AraC/XylS family, to which MarA belongs (Glasner et al. 2006). One or more of these regulatory proteins may be responsible for $a c r A$ induction by these phenolic acids.

Induction of the $e m r A B$ operon in enteric bacteria is under control of EmrR, which belongs to the MarR family of transcriptional regulators. Derepression of the emrAB operon in members of the family Enterobacteriaceae by SA takes place by interaction with EmrR (Lomovskaya et al. 1995). The $E$. chrysanthemi genome contains a highly homologous emrR gene contiguous with the $e m r A B$ operon. Therefore, our observation of induction of $e m r A$ gene expression in the presence of phenolic acids is not unexpected. Both AcrA and EmrA are periplasmic proteins that functionally interact with integral membrane proteins (AcrB and $\mathrm{EmrB}$, respectively) that are encoded in their cognate operons. We did not observe significant induction of $a c r B$ or $e m r B$ genes with phenolic acids in our microarray experiments. It is possible that differences in mRNA stability or the presence of regulatory structures within intercistronic regions of the operon encoding render these transcripts to be differentially expressed, as has been previously noted (Barabosa and Levy 2000).

The concentrations of phenolic acids at which we observed significant efflux pump gene expression in vitro are well within the range of these chemicals calculated to be present in infected plant tissue. The reported concentrations of SA in plants vary from 150 to $300 \mu \mathrm{M}$ in leaf tissue to $300 \mu \mathrm{M}$ in roots and $600 \mu \mathrm{M}$ in phloem exudates (Smith-Becker et al. 1998; Yalpani et al. 1993). SA is synthesized from pools of conjugated $\mathrm{BA}$, which then is converted to its aglycone by $\mathrm{BA}$ 2-hydroxylase (Leon et al. 1993). BA is formed from TC, which is derived from phenylalanine by PAL (Coquoz et al. 1998; Ribnicky et al. 1998; Yalpani et al. 1993). The first step in the pathway converting phenylalanine to $\mathrm{TC}$ has been shown to rise in pathogen-inoculated leaves continually for 18 $\mathrm{h}$ following infection (Smith-Becker et al. 1998).

In Escherichia coli, exposure to phenolic compounds results in enhanced expression of genes belonging to the mar operon (Cohen et al. 1993; Martin and Rosner 2002, 2004; Pomposiello et al. 2001). In addition, general stress response genes such as dnaK (heat shock), sulA (inhibition of cell division), $d p s$ (DNA-binding iron chelator), katE (catalase), and rpoS (global regulator) also are upregulated in the presence of phenolic compounds (Pomposiello et al. 2001). Our observations in E. chrysanthemi indicate that the primary response to phenolic acid exposure appears to be more specific and limited to antimicrobial agent and related stress resistance (Table 1), and does not include the general stress response genes. These differences may be due to the fact that studies with Escherichia coli used $5 \mathrm{mM}$ SA whereas, with E. chrysanthemi, we used a concentration of $0.078 \mathrm{mM}$ for each of the three phenolic acids.

Our data suggest that successful microbial pathogens like $E$. chrysanthemi can co-opt plant signaling chemicals such as phenolic acids that enhance tolerance to toxic plant antimicrobial chemicals. Studies on specific interactions between plantderived phenolic acids and regulatory proteins in E. chrysanthemi currently are underway to allow us to more fully understand the complex signaling that occurs between pathogen and host.

\section{MATERIALS AND METHODS}

Bacterial strains and growth of cells.

E. chrysanthemi 3937 was used in these studies. Luria-Bertani (LB) using only half the amount of $\mathrm{NaCl}$ was used as the growth medium for all experiments. Bacterial cells were grown in liquid culture and inoculated at $10^{6}$ cells $/ \mathrm{ml}$ into flasks for the in vitro studies. Cultures were grown for $18 \mathrm{~h}$ at $30^{\circ} \mathrm{C}$ and shaken, and viable cell counts were determined by serial dilution and plating. PB, CCCP, SA, BA, and TC were purchased from Sigma-Aldrich (St. Louis). Minimal inhibitory concentrations (MICs) of the drugs tested were determined using twofold dilutions of the chemicals in LB growth medium in microtiter plates as previously described (Barabote et al. 2003, Fralick 1996). The MIC is defined as the lowest concentration of a drug that prevented bacterial growth. Sub-MIC concentrations of CCCP and PB were 6 and $30 \mu \mathrm{g} / \mathrm{ml}$, respectively. All in vitro induction experiments utilized LB plus the inducer PA (a combination of phenolic acids SA plus TC plus $\mathrm{BA}$, each at $0.078 \mathrm{mM}$ ) unless stated otherwise. As a control for these experiments, the solvent DMSO was used at the same volume as the inducers.

\section{Construction of reporter gene fusions.}

An operon (transcription) fusion of acrA with the entire lux operon was constructed in wild-type E. chrysanthemi using pHSK728 carrying a promoterless lux operon downstream of a multiple cloning site (Shen et al. 1992). The PCRs using E. chrysanthemi 3937 chromosomal DNA as template were carried out using Promega buffers and Taq polymerase (Fisher), dNTPs (Otsu, Tokyo), and primers (Center for Biotechnology and Genomics, Texas Tech University) at the following final concentrations: $1 \times$ reaction buffer, $1.5 \mathrm{mM} \mathrm{MgCl}, 200 \mu \mathrm{M}$ NTPs, 100 pM primers, and 1 unit of Taq polymerase. All reactions were carried out on an MJ Research PTC-100 machine (Waltham, MA, U.S.A.). Products were electrophoresed on $0.8 \%$ agarose gels and purified using the QIAEXII purification kit (Qiagen, Valencia, CA, U.S.A.). Fragments were sequenced to confirm identity at the Center for Biotechnology and Genomics, Texas Tech University, and cloned into the pTOPO PCR2.1 vector (Invitrogen, Carlsbad, CA, U.S.A.). 
The promoter-containing fragment then was excised as an EcoRI fragment and cloned into pHSK728. The orientation of the cloned fragment was confirmed by nucleotide sequencing. The emrA::uidA reporter fusion was constructed in pBluescript (chloramphenicol-resistant)) following insertion of an uidA::npt cassette into the unique EcoRI site located in emrA to yield plasmid pSR2826.

\section{Efflux pump gene expression measurements.}

An overnight culture of approximately $10^{6}$ cells carrying acrA::luxAB or emrA::uidA fusions was added in a final volume of either $0.2 \mathrm{ml}$ (in microtiter plates) or $1 \mathrm{ml}$ of $\mathrm{LB}$ in tubes containing the appropriate inducers. Cells were incubated at $30^{\circ} \mathrm{C}$ for $90 \mathrm{~min}$. For luciferase activity, $50-\mu \mathrm{l}$ aliquots of cells were pipetted into 96-well white Costar plates and recorded using a Microplate Luminometer (Turner BioSystems, Sunnyvale, CA, U.S.A.). For $\beta$-glucuronidase activity, cells were washed once with $50 \mathrm{mM}$ potassium phosphate $(\mathrm{pH} 7.0$ ), and $25 \mu \mathrm{l}$ of toluene was added and allowed to evaporate after vortexing. The substrate p-nitrophenyl $\beta$-D-glucuronide was added at a final concentration of $3 \mathrm{mM}$ and incubated at $37^{\circ} \mathrm{C}$ for $30 \mathrm{~min}$. The reaction was stopped with an equal volume of $0.5 \mathrm{M} \mathrm{NaOH}$. The absorbance was measured at $405 \mathrm{~nm}$ using a Beckman DU 530 Spectrophotometer.

\section{In planta efflux pump gene expression.}

Heads of witloof chicory (Cichorium intybus L., Belgian endive) were purchased from a local supermarket. Overnightgrown cultures of appropriate bacterial strains were centrifuged and washed twice with $5 \mathrm{mM}$ morpholino-ethanesulfonic acid, $\mathrm{pH}$ 6.5, and resuspended in the same buffer. Chicory leaves were inoculated by introducing $10 \mu \mathrm{l}\left(10^{6}\right.$ cells $)$ of inoculum into a small wound created on the inner surface of each leaf using a sterile toothpick. Leaves were maintained in a moist chamber at $30^{\circ} \mathrm{C}$ for $90 \mathrm{~min}$ (Barabote et al. 2003). For acrA::lux, light was monitored using the Kodak Image station $440 \mathrm{CF}$. For the in situ $\beta$-glucuronidase enzyme assay, $10 \mu \mathrm{l}$ of toluene was added to the infection site to permeabalize cells and allowed to evaporate, and $10 \mu \mathrm{l}$ of $40 \mathrm{mM}$ 5-bromo-4chloro-3-indolyl- $\beta$-D-glucuronide was added to facilitate color development.

\section{Immunoblot analysis.}

Overnight cultures of E. chrysanthemi 3937 were centrifuged and washed twice in sterile phosphate buffered saline (PBS), $\mathrm{pH}$ 7.4 , and resuspended in same buffer. Whitloof chicory leaves were inoculated with $10^{6}$ cells and incubated at $30^{\circ} \mathrm{C}$ for 90 min (Barabote et al. 2003). As a control, cells were incubated in sterile PBS for $90 \mathrm{~min}$ at $30^{\circ} \mathrm{C}$. Cells were extracted from the leaf and optical density at $600 \mathrm{~nm}\left(\mathrm{OD}_{600}\right)$ measured to normalize cell number with the control. Immunoblot analysis was performed using Escherichia coli anti-AcrA rabbit antiserum following protein separation on $10 \%$ sodium dodecyl sulfate polyacrylamide gel electrophoresis and transfer to polyvinylidineflouride membranes according to standard procedures (Sambrook et al. 1989).

\section{Microarray experimental design and E. chrysanthemi 3937 coding sequence-specific oligonucleotide probe use.}

Flasks with $15 \mathrm{ml}$ of prewarmed LB were inoculated with $E$. chrysanthemi cells at approximately $10^{6}$ cells $/ \mathrm{ml}$ from an overnight culture, grown, and shaken at $150 \mathrm{rpm}$ at $30^{\circ} \mathrm{C}$ to midexponential growth $\left(\mathrm{OD}_{600}\right.$ of 0.4$)$ before addition of phenolic acids (0.078 mM each of SA, BA, and TC) (PA) or DMSO as a control. RNA was harvested from these cultures after 90 min as described below. For the microarray, RNA was prepared from three replicates of each inducer and control cultures.
The E. chrysanthemi 3937 coding sequences and a subset of the intergenic regions were selected and an initial set of candidate oligonucleotide probes designed using ArrayDesigner 1.17 (Premier Biosoft Int., Palo Alto, CA, U.S.A.). For all consecutive runs, the parameters were kept with constant values, as follows: Hairpin MaxDG was 5, SelfDimer MaxDG was 6, and Run/Repeat (dinucleotide) maximum length was 5. The final probes of 3937 were spotted using inkjet array technology to generate a 60 -mer $E$. chrysanthemi $11 \mathrm{~K}$ customer array (Agilent, Inc., Santa Clara, CA, U.S.A.), which contained 5,862 probes from the E. chrysanthemi genome (the entire open reading frame complement of Ech 3937), 20 Lucidea spikes (Lucidea Universal ScoreCard, Amersham Biosciences, Little Chalfont, U.K.), and internal controls. Two reciprocal (dye-swap) hybridizations were performed for normalization and replication purposes. Most of the probes were spotted twice onto a single array.

\section{cDNA synthesis, labeling, and hybridization.}

Total RNA from cells grown in LB plus PA or DMSO was isolated using a Qiagen RNA extraction Kit (Qiagen). RNA was quantified using a NanoDrop (NanoDrop, Wilmington, DE, U.S.A.) and quality checked using an Agilent Bioanalyzer 2100 (Agilent Technologies, Inc.). Total RNA (12 $\mu \mathrm{g})$ was used for cDNA synthesis, using SuperScript II (Invitrogen) following the manufacturer's instructions. cDNA, carrying aminoally-dUTP (Ambion, Austin, TX, U.S.A.), was labeled by $\mathrm{Cy} 3$ or Cy 5 and purified by Qiagen MinElute columns. The labeling efficiency was estimated using NanoDrop. Equivalent amounts of cDNA (control and sample) labeled with $\mathrm{Cy} 3$ or Cy5 were mixed with $25 \mu \mathrm{l}$ of control target and $105 \mu \mathrm{l}$ of $2 \times$ hybridization buffer (Agilent Technologies) and then assembled in a chamber for hybridization. Hybridization was carried out for $17 \mathrm{~h}$ at $60^{\circ} \mathrm{C}$ in an Agilent oven. After hybridization, the slides were washed at room temperature, then dried by spin. Arrays were scanned using an ArrayWoRx Auto scanner (Applied Precision, Inc., Issaquah, WA, U.S.A.) with various exposure settings for Cy3 (595 nm) and Cy5 (685 nm) at 9.756- $\mu \mathrm{m}$ resolution, generating separate TIFF images. Intensity data were acquired from images using SoftWoRx Tracker software. Images were imported and aligned with probe position (Agilent GAL file) using analyzerDG software automated and manual grid alignment features (SoftWoRx Tracker). Median signal spot and individual median background intensity values were extracted for each wavelength and imported into GeneSpring (v. 7.2; Agilent), whereby replicate spots in each array were averaged. Background-subtracted signals were corrected for unequal dye incorporation or unequal load of labeled product. The algorithm consisted of a rank consistency filter and normalization using the locally weighted linear regression (LOWESS) method. Saturated spots and the spots showing a reference signal lower than background were excluded from subsequent analyses. Based on standard deviation calculations, probes (genes) having $\geq 1.5$ or $\leq 0.66$ final sample/control (S/C) ratios were selected as statistically significant sample upregulated or sample downregulated. An increase or decrease of average signal log ratio from three biological replicates were evaluated by the GeneSpring software as significantly changed $(t$ test, $P$ value $\leq 0.05)$.

\section{Quantitative real-time RT-PCR analysis.}

RNA was isolated from cells induced with PA or DMSO as solvent control as described above. Reverse-transcriptase reactions were performed in a final volume of $100 \mu \mathrm{l}$, using random hexamers with the High Capacity cDNA Synthesis Kit according to the manufacturer's instructions (Applied Biosystems, Foster City, CA, U.S.A.). Substrate RNA (5 $\mu \mathrm{g})$ was 
used for each reverse-transcription reaction. Reaction mixtures were incubated at $25^{\circ} \mathrm{C}$ for $10 \mathrm{~min}$ followed by incubation at $37^{\circ} \mathrm{C}$ for $120 \mathrm{~min}$. Specific primer pairs were designed with the ABI PRISM Primer Express software (Applied Biosystems) (Table 2). The 16S rRNA gene was chosen as an internal standard.

Real-time RT-PCR was performed using SYBR Green PCR master mix (Applied Biosystems) according to the manufacturer's instructions. Primer pairs at a final concentration of 0.6 $\mu \mathrm{M}$ were used to amplify a 50-bp fragment for all three genes. Change in fluorescence emission was detected and analyzed with an ABI Prism 7000 Sequence Detection System (Applied Biosystems). Additional controls included omission of the reverse transcriptase to measure the extent of residual genomic DNA contamination, melting curve analysis, and use of a notemplate control for each primer pair to measure interference from primer dimer formation. Three replicates were performed for each reaction. A standard curve was generated using twofold dilutions of a known amount of the target gene as a template. PCR was performed using the following conditions: 1 cycle of $10 \mathrm{~min}$ at $95^{\circ} \mathrm{C}$ and 40 cycles of $94^{\circ} \mathrm{C}$ for $10 \mathrm{~s}, 55^{\circ} \mathrm{C}$ for $20 \mathrm{~s}$, and $72^{\circ} \mathrm{C}$ for $60 \mathrm{~s}$. To allow comparison of the relative expression levels of each gene, statistical analysis was carried out as previously described (Pfaffl 2001) using the 16S rRNAencoding gene as an internal control. This method requires verification of the efficiency of the PCR parameters and conditions used. To accomplish this, the efficiency of dye incorporation levels that resulted upon PCR with each primer set and a standardized amount of template DNA were determined using the formula $\mathrm{E}=10^{(-1 / \mathrm{slope})}$. These values then were used to normalize the results. The relative quantification of the genes of interest versus the $16 \mathrm{~S}$ rRNA encoding reference gene was accomplished using the following formula:

$$
\text { Ratio }=\left(\left[\mathrm{E}_{\text {target }}\right]^{\mathrm{Ct} \text { control - Ct sample }}\right) /\left(\left[\mathrm{E}_{\text {ref }}\right]^{\mathrm{Ct} \text { control }-\mathrm{Ct} \text { sample }}\right)
$$

where $\mathrm{Ct}$ control is the mean cycle threshold $(\mathrm{Ct}$; an arbitrary baseline fluorescence at which exponential amplification of gene of interest begins) of the control sample, $\mathrm{Ct}$ sample is the mean $\mathrm{Ct}$ of the test sample, $\mathrm{E}_{\text {target }}$ is efficiency of the production of target gene transcript, and $\mathrm{E}_{\mathrm{ref}}$ is efficiency of production of the reference gene transcript. The $\mathrm{Ct}$ values obtained from the Q-RT-PCR were confirmed using a paired $t$ test before application to the above formula.

\section{ACKNOWLEDGMENTS}

We thank J. Fralick and C. Lee for many helpful and stimulating discussions, J. Schrenzel and B. Gettler from the University Hospitals of Geneva, Switzerland, for their assistance in designing the microarray probes, and the Department of Biological Sciences for student support.

\section{LITERATURE CITED}

Alekshun, M., and Levy, S. B. 1999. Alteration of the repressor activity of MarR, the negative regulator of the Escherichia coli marRAB locus, by multiple chemicals in vitro. J. Bacteriol. 181:4669-4672.

Alekshun, M., and Levy, S. B., Mealy, T. R., Seaton, B. A., and Head, J. F. 2001. The crystal structure of MarR, a regulator of multiple antibiotic resistance, at 2.3 A resolution. Nat. Struct. Biol. 8:710-4.

Alfano, J. R., and Collmer, A. 1997. The type III (Hrp) secretion pathway of plant pathogenic bacteria: Trafficking harpins, Avr proteins, and death. J. Bacteriol. 179:5655-5662.

Barabosa, T. M., and Levy, S. B. 2000. Differential expression of over 60 chromosomal genes in Escherichia coli by constitutive expression of MarA. J. Bacteriol. 182:3467-3474.

Barabote, R. D., Johnson, O. L., Zetina, E., San Francisco, S. K., Fralick, J. A., and San Francisco, M. J. D. 2003. Erwinia chrysanthemi tolC is involved in resistance to antimicrobial plant chemicals and is essential for phytopathogenesis. J. Bacteriol. 185:5772-5778.

Bauer, D., Bogdanove, A., Beer, S., and Collmer, A. 1994. Erwinia chrysanthemi hrp genes and their involvement in soft rot pathogenesis and the elicitation of the hypersensitive response. Mol. Plant-Microbe Interact. 7:573-581.

Bina, J. E., and Mekalanos, J. J. 2001. Vibrio cholera tolC is required for bile resistance and colonization. Infect. Immun. 69:4681-4685.

Boccara, M., Mills, E. C., Jurgen, Z., Chiara, A., Chris, L., Robert, K. P., and Massimo, D. 2005. Flavohaemoglobin HmpX from Erwinia chrysanthemi confers nitrosative stress tolerance and affects the plant hypersensitive reaction by intercepting nitric oxide produced by the host. Plant J. 43:226-237.

Borges-Walmsley, M., and Walmsley, A. 2001. The structure and function of drug pumps. Trends Microbiol. 9:71-79.

Burse, A., Weingart, H., and Ullrich, M. S. 2004a. NorM, an Erwinia amylovora multidrug efflux pump involved in in vitro competition with other epiphytic bacteria. Appl. Environ. Microbiol. 70:693-703.

Burse, A., Weingart, H., and Ullrich, M. S. 2004b. The phytoalexin-inducible multidrug efflux pump AcrAB contributes to virulence in the fire blight pathogen, Erwinia amylovora. Mol. Plant Microbe-Interact. 17:43-54.

Chong, J., Pierrel, M. A., Atanassova, R., Werck-Reichhart, D., Fritig, B. and Saindrenan, P. 2001. Free and conjugated benzoic acid in tobacco plants and cell cultures: Induced accumulation upon elicitation of defense responses and role as salicylic acid precursors. Plant Physiol. 125:318 328 .

Cohen, S. P., Hachler, H., and Levy, S. B.1993. Genetic and functional analysis of the multiple antibiotic resistance (mar) locus of Escherichia coli. J. Bacteriol. 175:1484-1492.

Collmer, A., and Keen, N. T. 1986. The role of pectic enzymes in plant pathogenesis. Annu. Rev. Phytopathol. 24:383-453.

Conter, A., Gangneux, C., Suzanne, M., and Gutierrez, C. 2001. Survival of Escherichia coli during long-term starvation: Effects of aeration, $\mathrm{NaCl}$ and the rpoS and osmC gene products. Res. Microbiol. 152:17-26.

Coquoz, J.-L., Buchala, A., and Metraux, J. P. 1998. The biosynthesis of salicylic acid in potato plants. Plant Physiol. 117:1095-1101.

Cowan, M. M. 1999. Plant products as antimicrobial agents. Clin. Microbiol. Rev. 12:564-582.

Dangl, J. 1998. Plants just say NO to pathogens. Nature 394:525-256.

Delaney, T. P., Uknes, S., Vernooij, B., Friedrich, L., Weymann, K., Negrotto, D., Gaffney, T., Gut-Rella, M., Kessmann, H., Ward, E., and Ryals, J. 1994. A central role of salicylic acid in plant disease resistance. Science 266:1247-1250.

Dixon, R. J. 2001. Natural products and plant disease resistance. Nature 411:843-847.

Eaton, D. L., and Bammler, T. K. 1999. Concise review of the glutathione Stransferases and their significance to toxicology. Toxicol. Sci. 49:156-164.

El Hassouni, M., Chambost, J. P., Expert, D., Van Gijsegem, F., and Barras, F. 1999. The minimal gene set member, $m s r A$, encoding peptide methionine sulfoxide reductase, is a virulence determinant of the plant pathogen Erwinia chrysanthemi. Proc. Natl. Acad. Sci. U.S.A. 96:887892.

Feys, B., and Parker, J. E. 2000. Interplay of signaling pathways in plant disease resistance. Trends Genet. 16:449-455.

Fralick, J. 1996. Evidence that TolC is required for functioning of the Mar/AcrAB efflux pump of Escherichia coli. J. Bacteriol. 178:58035805.

Glasner, J. D., Yang, C.-H., Reverchon, S., Hugouvieux-Cotte-Pattat, N., Condemine, G., Bohnin, J.-P., Van Gijsegem, F., Yang, S. H., Franza, T., Expert, D., Plunkett, G., III, San Francisco, M. J. D., Charkowski, A., Py, B., Bell, K., Rauscher, L., Rodriguez-Palenzuela, P., Toussaint, A., Holvea, M., He, S.-Y., Douet, V., Boccara, M., Blanco, C., Toth, I., Anderson, B. D., Biehl, B. Mau, B., Flynn, S. M., Barras, F., Lindeberg, M., Birch, P., Tsuyumu, S., Shi, X., Hibbing, M., Yap, M.-N., Carpentier, M., Dassa, E., Umehara, M., Kim, J. F., Rusch, M., Soni, P., Mayhew, G. F., Fouts, D., Gill, S., Blattner, F. R., Keen, N. T., and Perna, N. T. 2006. Analysis of the Erwinia chrysanthemi 3937 genome. ASAP database. University of Wisconsin, School of Veterinary Medicine, Animal Health and Biomedical Sciences. ASAP database. Published online.

Gonzalez-Pasayo, R., and Martinez-Romero, E. 2000. Multiresistance genes of Rhizobium etli CFN42. Mol. Plant-Microbe Interact. 13:572-7.

Greenberg, J. T. 1996. Programmed cell death: A way of life for plants. Proc. Natl. Acad. Sci. U.S.A. 93:12094-12097.

Grkovic, S., Brown, M. H., and Skurray, R. A. 2001. Transcriptional regulation of multidrug efflux pumps in bacteria. Cell Dev. Biol. 12:225-237.

Hahn, M. G., Darvill, A. G., and Albersheim, P. 1981. Host-pathogen interactions. XIX. The endogenous elicitor, a fragment of a plant cell wall polysaccharide that elicits phytoalexin accumulation in soybeans. Plant Physiol. 68:1161-1169.

Hammerschmidt, R. 1999. Phytoalexins: What have we learned after 60 years? Annu. Rev. Phytopathol. 37:285-306.

Hugouvieux-Cotte-Pattat, N., Condemine, G., Nasser, W., and Reverchon, S. 1996. Regulation of pectinolysis in Erwinia chrysanthemi. Annu. Rev. Microbiol. 50:213-257. 
Klessig, D., Durner, J., Noad, R., Navarre, D., Wendehenne, D., Kumar, D., Zhou, J., Shah, J., Zhang, S., Kachroo, P., Trifa, Y., Pontier, D., Lam, E., and Silva, H. 2000. Nitric oxide and salicylic acid signaling in plant defense. Proc. Natl. Acad. Sci. U.S.A. 97:8849-8855.

Koronakis, V, Sharff, A., Koronakis, E., Luisi, B., and Hughes, C. 2000. Crystal structure of the bacterial membrane protein TolC central to multidrug efflux and protein export. Nature 405:914-919.

Leon, J., Yalpani, N., Raskin, I. and Lawton, M. A. 1993. Induction of benzoic acid 2-hydroxylase in virus-inoculated tobacco. Plant Physiol. 103:323-328.

Lomovskaya, O., Lewis, K., and Matin, A. 1995. EmrR is a negative regulator of the Escherichia coli multidrug resistance pump EmrAB. J. Bacteriol. 177:2328-34.

Lopez-Solanilla, E., Garcia-Olmedo, F., and Rodriguez-Palenzuela, P. 1998. Inactivation of the $s a p F$ to sapA locus of Erwinia chrysanthemi reveals common features in plant and animal bacterial pathogenesis. Plant Cell 10:917-924.

Lopez-Solanilla, E., Llama-Palacios, A., Collmer, A., Garcia-Olmedo, F. and Rodriguez-Palenzuela, P. 2001. Relative effects on virulence of mutations in the sap, pel, and hrp loci of Erwinia chrysanthemi. Mol. Plant-Microbe Interact. 14:386-393.

Martin, R. G., and Rosner, J. L. 2002. Genomics of the marA/soxS/rob Regulon of Escherichia coli: Identification of directly activated promoters by application of molecular genetics and informatics to microarray data. Mol. Microbiol. 44:1611-1624.

Martin, R. G., and Rosner, J. L. 2004. Transcriptional and translational regulation of the $\operatorname{mar} A B$ multiple antibiotic resistance operon in $E s$ cherichia coli. Mol. Microbiol. 53:183-191.

Mauch-Mani, B., and Slusarenko, A. 1996. Production of salicylic acid precursors is a major function of phenylalanine ammonia-lyase in the resistance of Arabidopsis to Peronospora parasitica. Plant Cell 2:203-212.

Miller, P., and Sulavik, M. 1996. Overlaps and parallels in the regulation of intrinsic multiple-antibiotic resistance in Escherichia coli. Mol. Microbiol. 21:441-448.

Murakami, S., Nakashima, R., Yamashita, E., and Yamaguchi, A. 2002. Crystal structure of bacterial multidrug efflux transporter AcrB. Nature 419:587-593.

Nachin, L., Hassouni, M. Loiseau, L. Expert, D, and Barras, F. 2001. SoxR dependant response to oxidative stress and virulence of Erwinia chrysanthemi the key role of SufC, an orphan ABC ATPase. Mol. Microbiol. 39:960-972.

Nikaido, H. 1996. Multidrug efflux pumps of gram-negative bacteria. J. Bacteriol. 178:5853-5859.

Okinaka, Y., Yang, C.-H, Perna, N. T., and Keen, N. T. 2002. Microarray profiling of Erwinia chrysanthemi 3937 genes that are regulated during plant infection. Mol. Plant-Microbe Interact. 15:619-629.

Otto, K., and Hermansson, M. 2004. Inactivation of ompX causes increased interactions of type 1 fimbriated Escherichia coli with abiotic surfaces. J. Bacteriol. 186:226-234

Palumbo, J. D., Kado, C. I., and Phillips, D. A. 1998. An isoflavonoidinducible efflux pump in Agrobacterium tumefaciens is involved in competitive colonization of roots. J. Bacteriol. 180:3107-3113.
Pfaffl, M. W. 2001. A new mathematical model for relative quantification in real-time RT-PCR. Nucleic Acids Res. 29:E45-E45.

Pieterse, C., and Van Loon, L. C. 1999. Salicylic acid-independent plant defence pathways. Trends Plant Sci. 4:52-58.

Pomposiello, P. J., Bennik, M. H., and Demple, B. 2001. Genome-wide transcriptional profiling of the Escherichia coli responses to superoxide stress and sodium salicylate. J. Bacteriol. 183:3890-3902.

Randall, L. P., and Woodward, M. J. 2001. Multiple antibiotic resistance (mar) locus in Salmonella enterica serovar typhimurium DT104. Appl. Environ. Microbiol. 67:1190-1197.

Rhee, S. R., Martin, R. G., Rosner, J. L., and Davies, D. R. 1998. A novel DNA-binding motif in MarA: The first structure for an AraC family transcriptional activator. Proc. Natl. Acad. Sci. U.S.A. 95:1041310418.

Ribnicky, D. M., Shulaev, V., and Raskin, I. 1998. Intermediates of salicylic acid biosynthesis in tobacco. Plant Physiol. 118:565-572.

Rosner, J. L. 1985. Nonheritable resistance to chloramphenicol and other antibiotics induced by salicylates and other chemotactic repellents in Escherichia coli K-12. Proc. Natl. Acad. Sci. U.S.A. 82:8771-8774.

Ryan, C. A., and Farmer, E. E. 1991. Oligosaccharide signals in plants: A current assessment. Annu. Rev. Plant Physiol. Plant Mol. Biol. 42:651674.

Sambrook, J., Fritsch, E. F., and Maniatis, T. 1989. Molecular Cloning: A Laboratory Manual. Cold Spring Harbor Laboratory Press, Cold Spring Harbor, NY, U.S.A.

Shen, H., Gold, S. Tamaki, S., and Keen, N. T. 1992. Construction of a Tn7-lux system for gene expression studies in gram-negative bacteria. Gene 122:27-34.

Smith-Becker, J., Marois, E., Huguet, E. J., Midland, S. L., Sims, J. J., and Keen, N. T. 1998. Accumulation of salicylic acid and 4-hydroxybenzoic acid in phloem fluids of cucumber during systemic acquired resistance is preceded by a transient increase in phenylalanine ammonia lyase activity in petioles and stems. Plant Physiol. 116:231-238.

Stone, B. J., and Miller, V. L. 1995. Salmonella enteritidis has a homologue of tolC that is required for virulence in $\mathrm{BALB} / \mathrm{c}$ mice. Mol. Microbiol. 17:701-12.

Tenhaken, R., Levine, A., Brisson, L. F., Dixon, R. A., and Lamb, C. 1995 Function of the oxidative burst in hypersensitive disease resistance. Proc. Natl. Acad. Sci. U.S.A. 92:4158 4163.

Valecillos, A. M., Palenzuela, P. R, and Lopez-Solanilla, E. 2006. The role of several multidrug resistance systems in Erwinia chrysanthemi pathogenesis. Mol. Plant-Microbe Interact. 19:682-694.

Van Loon, L. C. 2000. Systemic induced resistance. Pages 521-574 in: Mechanisms of Resistance to Plant Diseases. A. J. Slusarenko, R. S. S. Fraser, and L. C. Van Loon, eds. Kluwer Academic Publishers, Dordrecht, The Netherlands.

Wildermuth, M. C., Dewney, J., Wu, G., and Ausubel, F. M. 2001. Isochorismate synthetase is required to synthesize salicylic acid for plant defense. Nature 414:562-565.

Yalpani, N., Leon, J., Lawton, M. A., and Raskin, I. 1993. Pathway of salicylic acid biosynthesis in healthy and virus-inoculated tobacco. Plant Physiol. 103:315-321. 